\title{
Assessing the Field Course Experiential Learning Model: Transforming Collegiate Short-term Study Abroad Experiences into Rich Learning Environments
}

\author{
J a c que line S. M c La ugh Iin
}

The Pennsylvania State University, Lehigh Valley

\section{K e n t J o h n so n}

The University of Oklahoma

\section{Introd uction}

Constructivist learning theory holds that "learning consists less in recording information than in interpreting it. To interpret what is received and is attended to, the learner must personally construct meaning for it" (Wubbels and Girgus, 1997). Unfortunately, opportunities for interpreting conceptual information are often lacking in classroom environments-particularly in the area of biological science. Every biology student needs to understand thoroughly the concept of "biodiversity," particularly because the biosphere and many of its life forms are threatened (Brook, 2003; McKee, 2004, Pounds, 2004; Pimm, 1995; Sala, 2000; Wilson, 2002, Archard et al., 2003; Rosser and Mainka, 2002; Thomas et al., 2004; Secretariat of the Convention on Biological Diversity, 2006). This urgency necessitates reexamining how students learn and redesigning learning environments to facilitate student learning, especially when failure to engage students in scientific disciplines risks "...producing a society with little scientific literacy at a time when such literacy is needed more than ever..." (Wubbels and Girgus, 1997). Scientific instruction and its assessment are often based on equating "rote learning" with student learning gains. Unfortunately, while these gains are conveniently guided by essentialist and objectivist philosophies that assume scientific learning is memorizing bits of information, they fail to promote higher-order cognitive abilities necessary for the development of scientific literacy (Project Kaleidoscope, 1991). 
By contrast, constructivist environments in science are created by learning experiences that are "active, hands-on, lab-rich, curricularly lean, connected to contexts, and enmeshed in a community of learners" (Wubbels and Girgus, 1997). Field-based learning provides an ideal environment for constructivist learning that promotes deep scientific understanding in conservation biology and biodiversity. The "Field Course Experiential Learning Model" (Zervanos and McLaughlin, 2003; McLaughlin, 2005) evolved from repeated short-term study abroad field course experiences in selected biomes from around the world over a six-year period. Assessment of student learning guided the development of an integrated course model featuring three steps: 1) innovative web-based pre-trip assignments that provide essential background knowledge; 2) a field-based trip experience that includes hands-on experience, journal keeping, environmental science, and basic conservation research, participation in discussion groups, species assignments, and independent exploration; and 3) post-trip web-based assignments that encourage the integration and application of key concepts learned. This design facilitates increased understanding of biodiversity and conservation biology through encouraging students to become active participants in their own education. Learning is further enhanced through interdisciplinary perspectives incorporating principles of biology, ecology, environmental science, geography, economics, sociology, political science, history, and other disciplines. Interdisciplinary perspectives promote learning through addressing principle sources of curricular incoherence including irrelevance, information under/over load, obscurity or indirectness, and inaccuracy (Johnson and Ratcliff, 2004). This paper reports assessment findings from three cohorts of students participating in a short-term study abroad field course experience in Costa Rica, entitled, Environmental Science and Conservation Biology: A Field Study in the Biodiversity of Costa Rica, using the 'Field Course Experiential Learning Model' as its pedagogical framework. It describes cognitive and affective learning gains of students participating in the course.

\section{I mportance of the Three steps}

The strength of the "field course experiential learning model" is its three steps, which can be defined roughly as 1) pre-trip preparation, 2) trip experience, and 3) post-trip synthesis. This model facilitates critical thinking and illustrates the scientific process - inquiry — in action. As a result, pre-trip preparation assignments don't exist in a void; they inform an anticipated experience and elicit inquiry. Likewise, field work experience is conducted by students as field researchers who have become intimately familiar with the environment. 
Hands-on/minds-on work in the "field" is integral to the course and its learning model. Facts gathered during the pre-trip stage are made "real" when manifested in nature. These manifestations then illuminate post-trip analysis-providing the "hard data" from which learning is synthesized. Assessments taken at each stage provide insight into learning and generate data useful in refining pre-trip, trip, post-trip activities for future use. In particular, field journals allow learners to synthesize and reflect upon their daily experiences-be they scientific, political, cultural or personal.

\section{Preparation}

To get a better idea of the model's functionality, consider its application to the 2004 Costa Rica course. During the pre-trip stage, each student had to complete web-based activities and research that provided essential background knowledge pertaining to their upcoming field work in Costa Rica (Appendix A). Additionally, since all students are required to lead a 30-minute presentation in the field followed by a group discussion on a related topic (specifically one that directly pertains to environmental science and/or conservation biology), presentation topics were identified and researched during this stage of the course (Appendix B).

\section{Experience}

During the three-week Costa Rica trip, students performed daily fieldbased basic research in areas of environmental science and conservation biology, supplemented with real-world ecosystem exploration, peer presentations and discussions, and species assignments. One of the venues visited was the Caribbean Conservation Corporation's (CCC) John H. Phipps Biological Field Station in Tortuguero (www.cccturtle.org), which stretches for 30 kilometers along the Caribbean coast and protects many species of endemic plants, sea turtles, the last remaining refuge for manatees, and is the only remaining structurally-intact mangrove on Costa Rica's Atlantic coast. Also visited was the Asociación ANAI Field Station in Gandoca/Manzanillo (www.anaicr.org) located in the Talamanca region. The 3000 square kilometers that form Talamanca contain a staggering two percent of our planet's biodiversity, 30 to $40 \%$ of which is found nowhere else on Earth. Talamanca's natural features include steep mountainsides, rich alluvial plains, large expanses of wetlands and, offshore, a variety of marine ecosystems including Costa Rica's only coral reef. The final site visited in the course was the lush tropical forests of La Selva Biological Station managed by the Organization of Tropical Studies (OTS) (www.ots.duke.edu/en/laselva) which 
is located at the confluence of two major rivers in the Caribbean lowland of northern Costa Rica. La Selva comprises 1,600 hectares (3,900 acres) of tropical wet forests and disturbed lands. It averages four meters (over 13 feet) of rainfall that is spread rather evenly throughout the year.

To maximize the field experience, students were also required to maintain a daily journal, attend research presentations at field stations, and record, evaluate and report all data gathered from daily research activities.. These activities included gathering data with established researchers from all over the world on sea turtle nesting, hatchling migration, amphibian natural defenses, rainforest productivity and carbon cycling, global warming, stream ecosystems dynamics, and bird and/or mammal population density at the aforementioned research stations. Students were also required to complete species assignments (see Appendix C).

\section{Synthesis}

Once back home, the post-trip stage consisted of reflective activities and Web-based assignments that encouraged the integration and application of key concepts learned (Appendix D). For students, a significant part of the "synthesis" stage is devoted to translating the principles of experiential learning to their own immediate surroundings and daily life.

\section{Integrating Assessment into the Course Design}

Creating and assessing constructivist learning environments aim at developing higher- order thinking skills. A goal of this course was to move students beyond knowledge learning domains to higher order learning domains of application and integration (Bloom, 1956; Anderson and Krathwohl, 2001). This goal suggests using a different set of conceptual tools to evaluate learning by allowing students to demonstrate how they can apply and integrate knowledge. For this reason, the course design featured embedded performance assessments of students' scientific knowledge. Performance assessments require students to perform authentic tasks that demonstrate knowledge and skills gained. Because an expectation of this course was that students demonstrate the ability to apply scientific theory to describe an environment, students were asked to journal their experience daily. These journal activities are similar to field journals used by scientists to organize and document field observations. The process meets criteria for authentic assessment as it replicates an activity in which scientists engage. Additionally, the journal activity gave students the opportunity to construct knowledge in a way that both encouraged and provided evidence of higher-order thinking. 
Student journal entries were analyzed using a rubric designed to evaluate the cognitive level of their entries based on Bloom's Taxonomy (Bloom, et al., 1956). This article discusses learning gains in four areas. Figure 1 provides an example of the holistic rubric used to assess student learning gains in these four scientific concepts. The descriptors in the rubric were designed to guide the assessment team in evaluating the cognitive level of learning experienced by

Figure 1: Examples from a Rubric for Assessing Cognitive Learning Levels of Students

\begin{tabular}{|c|c|c|c|}
\hline \multirow{2}{*}{$\begin{array}{l}\text { Scientific } \\
\text { Concept }\end{array}$} & \multicolumn{3}{|c|}{ Demonstrated Cognitive Level } \\
\hline & Knowledge & Comprehension & Application \\
\hline HIPPO & $\begin{array}{l}\text { Student recalled and } \\
\text { defined HIPPO in } \\
\text { their journal entries. }\end{array}$ & $\begin{array}{l}\text { Student was able } \\
\text { to demonstrate } \\
\text { understanding } \\
\text { through describing } \\
\text { an environmental } \\
\text { phenomenon using } \\
\text { HIPPO categories. }\end{array}$ & $\begin{array}{l}\text { Student demon- } \\
\text { strated a deep } \\
\text { understanding of } \\
\text { HIPPO categories } \\
\text { through elaborating } \\
\text { potential environ- } \\
\text { mental solutions } \\
\text { to problems associ- } \\
\text { ated with human/ } \\
\text { environmental } \\
\text { interactions. }\end{array}$ \\
\hline $\begin{array}{c}\begin{array}{c}\text { Disturbance } \\
\text { and }\end{array} \\
\text { Community } \\
\text { Structure }\end{array}$ & $\begin{array}{l}\text { Student defined } \\
\text { disturbance and } \\
\text { community } \\
\text { structure. }\end{array}$ & $\begin{array}{l}\text { Student observed } \\
\text { an environmental } \\
\text { phenomenon and } \\
\text { described the } \\
\text { relationship of } \\
\text { a disturbance } \\
\text { to community } \\
\text { structure. }\end{array}$ & $\begin{array}{l}\text { Student used an } \\
\text { environmental } \\
\text { observation to } \\
\text { develop cause/ef- } \\
\text { fect models as they } \\
\text { relate to disturbance } \\
\text { and community } \\
\text { structure. }\end{array}$ \\
\hline Succession & $\begin{array}{l}\text { Students defined } \\
\text { succession. }\end{array}$ & $\begin{array}{l}\text { Students observe } \\
\text { and describe succes- } \\
\text { sion in the context } \\
\text { of a natural or } \\
\text { human disaster. }\end{array}$ & $\begin{array}{l}\text { Students elaborate } \\
\text { on description } \\
\text { of succession to } \\
\text { develop mental } \\
\text { models describing } \\
\text { the changes the } \\
\text { potential changes } \\
\text { that will follow. }\end{array}$ \\
\hline $\begin{array}{l}\text { Rainforest } \\
\text { Ecosystems }\end{array}$ & $\begin{array}{l}\text { Students listed and } \\
\text { defined different } \\
\text { types of rainforests } \\
\text { found in Costa Rica. }\end{array}$ & $\begin{array}{l}\text { Students observed } \\
\text { differences in rain } \\
\text { forests, described } \\
\text { differences in } \\
\text { context of layers, } \\
\text { vegetation, and } \\
\text { climatic zones. }\end{array}$ & $\begin{array}{l}\text { Student elaborated } \\
\text { relation of differ- } \\
\text { ences in forest } \\
\text { abiotic factors to } \\
\text { types of vegeta- } \\
\text { tion and/or wildlife } \\
\text { within the specific } \\
\text { forest type. }\end{array}$ \\
\hline
\end{tabular}


students as described through their field journals. Additional items described in the full version of the rubric included natural selection, policy-environment relationships, and human-environment relationships.

The journal assignment was unscripted. Students were asked simply to make observations in the field and record them. They were not instructed to connect field observations to pre-trip readings and trip presentations as we wanted to see if those connections would be voluntarily constructed by students.

The embedded performance assessment was supplemented by a post-trip assignment in which students provided open-ended responses to questions. The purpose of the assignment was to help students connect readings and the field experience and to provide an opportunity to demonstrate their level of learning. The post-trip assignment used a prompted protocol asking students to describe observations made in the field in the context of the scientific models presented in their readings. A Student Assessment of Learning Gains was also designed and used to assess students' perceived learning gains. The assessment instrument asked students to rate the extent to which specific learning activities contributed to specific knowledge and skill outcomes. For example, students were asked to rate the extent to which the field experience contributed to their understanding of basic principles of biodiversity, to their understanding of the relationship between human activity and the environment, and other general knowledge domains. In addition, similar questions explored how the experience contributed to gains in scientific skills and to higher-order cognitive gains. Following each set of ratings, students were provided the opportunity to post responses on their learning in an open response format. The findings are based on analysis of 62 students over three courses to Costa Rica, with each program lasting approximately three weeks.

\section{Fin d ing s}

\section{Embedded Assessments of Unstructured Journal Entries}

Pre-trip assignments introduced students to major environmental science and conservation biology concepts. The intent of the assignments was to provide a common level of "prior learning" for students. The actual field experiences in Costa Rica were structured to build on this "prior learning" to help students make knowledge gains in biodiversity and conservation biology concepts. Journals provided an opportunity for students to demonstrate how field observations and activities contributed to their understanding of biodiversity and conservation biology concepts. 
As described in the methods section, each student's journal was assessed using rubrics organized by cognitive learning level. Figure 2 illustrates how the rubrics were applied using three examples of student descriptions of the concept of disturbance observed on a hike in the Arenal Volcano area.

\section{Figure 2: $\quad$ Example of Rubric Application to Student Entries on Disturbance}

\begin{tabular}{|c|c|c|}
\hline Knowledge & Comprehension & Application \\
\hline $\begin{array}{l}\text { The Arenal Volcano } \\
\text { erupted in 1968. The lava } \\
\text { destroyed everything in } \\
\text { its path and left behind } \\
\text { only hardened rock. }\end{array}$ & $\begin{array}{l}\text { The Arenal Volcano first } \\
\text { erupted in } 1968 \text { leaving } \\
\text { all vegetation to grow in } \\
\text { the last } 30 \text { years. Lichens } \\
\text { are growing all around } \\
\text { and ferns and grasses are } \\
\text { beginning to grow back. }\end{array}$ & $\begin{array}{l}\text { It was amazing to see how } \\
\text { life springs up from noth- } \\
\text { ing but hardened lava } \\
\text { flows that contain ma- } \\
\text { terials which were once } \\
\text { deep below the Earth's } \\
\text { curst. First, lichens form } \\
\text { and they secrete an acid } \\
\text { that breaks down the } \\
\text { rocks into soil. Mosses } \\
\text { also grow on the rocks. } \\
\text { We saw this as we hiked } \\
\text { across the rocks at the } \\
\text { base of the volcano. The } \\
\text { rocks were from a } 1993 \\
\text { Volcano. After the mosses } \\
\text { come grasses, ferns, then } \\
\text { bushes and shrubs and } \\
\text { finally the trees. }\end{array}$ \\
\hline
\end{tabular}

Application of the rubric across all domains revealed that students field notes varied in emphasis ranging from simple descriptions of the days' observations and events (knowledge domain) to complex descriptions of biological concepts observed (application domain). Of the 62 journals evaluated, four students failed to provide responses, suggesting they had moved beyond a knowledge domain. The remainder of students (58) provided at least one entry in which they demonstrated learning at a comprehension level in each learning domain reported (i.e. HIPPO, Disturbance, Succession, and Rain Forest Ecosystems) and also provided evidence in one of the domains at the application level. An additional 24 students provided at least two journal entries that demonstrated learning at the application level in two domains. A further ten students demonstrated learning at an application level in two to three domains and five students made between four and six entries that demonstrated learning at an application level in all four domains assessed. 


\section{Assessment of Prompted Post-trip Assignment}

It was no surprise that students were more likely to demonstrate learning at an application level in the structured assignments. Two of the post-trip assignments prompted responses at the application level, the species assignment (Appendix C) and Questions D, E, and F in the "Post-trip Questions" (Appendix D). The rubric designed to assess the journals was applied to assess student learning in the post-trip assignments. Given prompts, all but two students managed to demonstrate learning gains at the application level. The following response to a question on biodiversity in the rainforest illustrates the type of learning that occurred for the majority of students:

The Costa Rican rainforests vary in diversity based on elevation, temperature and rainfall. There are five types of forests in CR based on these differing parameters: alpine forest (paramo), cloudforest, lowland tropical wet forest, highland tropical wet forest, and lowland tropical dry forest. Also playing a factor is whether or not it was a virgin forest or not. Primary growth forests, or "old growth forests," have trees of varying diameters, including some huge trees with large buttress roots, and lots of vines and epiphytes. Here natural disturbance is high and it's easy to walk through the understory which is covered with mostly palms and is not very dense. In a secondary growth forest, the understory is very dense with a wide variety of plant species, the trees are all the same diameter, and the total amount of biodiversity is less. Usually, secondary forests have only one canopy layer, whereas old growth forests have several.

\section{Student Assessment of Learning Gains}

To confirm how the learning experience contributed to specific learning gains, the survey asked students to describe the extent to which they made specific learning gains in specific knowledge domains. Students rated their learning on a five point scale ( $1=$ not at all; $5=$ a great deal). The domains and the student ratings are described in Table 1 as means.

The ratings suggest that students perceived making strong gains in each of the areas. Analysis of their course assignments is consistent with these ratings. Student comments accent the value of the course design in contributing to knowledge gains as reported by one student: "Wow! I have never learned so much in such a short amount of time, or remembered so much of it! The stuff learned is still in my head, everyday, unlike other classes that you forget all the things you learned. We experienced what we were learning, and that made all 
the difference." Another student wrote, "The purpose of this course was to learn about biodiversity. It did just that. My favorite part of the trip was the discussion on how humans impact biodiversity. I gained a great deal from that discussion." Another student stated, "Our field guide really knew a lot about nature and the people of Costa Rica. He made great connections illustrating cause and effect relationships. We traveled much of the country, so I feel I know a lot about the geography and culture. We met many different types of Ticos who shared their opinions and feelings about conservation and human activities."

Students gave slightly lower ratings on skill gains. The slightly lower ratings may be due in part to the collaborative processes in the field and the possibility that students did not perceive they were doing independent work, or therefore developing specific individual skills . Additionally, student journals indicate that some confusion might have existed, since entries discussed field experiments and observations rather than field-based research projects. However, as illustrated in Table 2, students ranked the skill gains as being fairly strong.

Table 1: $\quad$ Student Reported Gains in Knowledge

\begin{tabular}{|l|c|c|}
\hline Knowledge Gained & Rating & $\begin{array}{c}\text { Standard } \\
\text { Deviation }\end{array}$ \\
\hline Basic principles of biodiversity & 4.71 & 0.45 \\
\hline $\begin{array}{l}\text { How human activities impact biodiversity and } \\
\text { ecosystem stability }\end{array}$ & 5.00 & 0.0 \\
\hline Culture and geography of Costa Rica & 4.43 & 0.73 \\
\hline Conservation biology as it relates to Costa Rica & 4.71 & 0.45 \\
\hline Conservation biology in general & 4.43 & 0.73 \\
\hline Biocomplexity of ecosystems & 4.43 & 0.73 \\
\hline Community ecology & 4.29 & 1.03 \\
\hline
\end{tabular}

Table 2: $\quad$ Student Reported Gains in Skills

\begin{tabular}{|l|c|c|}
\hline Skills Gained & Rating & $\begin{array}{c}\text { Standard } \\
\text { Deviation }\end{array}$ \\
\hline Applying basic biological principles to field study & 4.57 & 0.49 \\
\hline Communicating through writing & 3.63 & 1.29 \\
\hline Conducting field research & 4.16 & 0.46 \\
\hline Presenting information effectively to others & 4.31 & 1.17 \\
\hline Working as a team to increase learning & 4.44 & 0.64 \\
\hline
\end{tabular}


Student comments suggest that the skills learned were perceived as lifelong and applicable to multiple areas of their lives beyond environmental science. One student stated that, “The trip not only increased my learning, but increased my writing, research, and communication skills. Through presentations and assignments, I soon became comfortable around my peers and working and discussing in the field." Another student noted that, "I think that the writings and the talks help us with our communication skills. Working as a team also teaches us tolerance, respect for others ideas, and teaches us to depend on others and to get along with others." These important life skills appear to prepare students better for future coursework in any discipline and for life after their formal education.

Students were also asked to report the extent to which they made gains in conceptual knowledge as a result of the course. Table 3 describes their ratings of these gains reported as means on the same 1 to 5 scale.

\section{Table 3: $\quad$ Student Reported Conceptual Learning Gains}

\begin{tabular}{|l|c|c|}
\hline Conceptual Learning Gains & Rating & $\begin{array}{c}\text { Standard } \\
\text { Deviation }\end{array}$ \\
\hline $\begin{array}{l}\text { Understanding the concepts of biodiversity as } \\
\text { they relate to tropical rain forests. }\end{array}$ & 4.57 & 0.49 \\
\hline $\begin{array}{l}\text { Understanding how human and social activity impacts } \\
\text { biodiversity }\end{array}$ & 4.57 & 0.49 \\
\hline $\begin{array}{l}\text { Understanding how societal decision making alters } \\
\text { biodiversity }\end{array}$ & 4.43 & 0.73 \\
\hline Ability to make informed decisions on ecological issues & 4.57 & 0.49 \\
\hline Thinking critically about complex conservation issues. & 4.43 & 0.73 \\
\hline $\begin{array}{l}\text { Ability to think through a problem or argument as it } \\
\text { pertains to the environment }\end{array}$ & 4.14 & 0.83 \\
\hline
\end{tabular}

The value of these learning experiences was expressed clearly by a student who wrote:

I think anytime that you talk about the environment and solving its problems you are going to have people who are extremely opposed to any kind of conservation. If it comes to the environment and big business, the environment often loses. It is very complex trying to let people continue to make a living off of the environment while still trying to protect it. How do you tell someone how much damage that they cause to the environment or stop them form causing that damage when they make their living from 
logging or developing the land for housing communities. Or is it ethical to tell people they can only have so many children. The boundaries are not defined in black and white. But at some point man is going to have to realize that we need to respect the land we live on. We have become a throw away society, but it is our own country that we are destroying and once we have destroyed it to a point, there will be no place left for us.

As illustrated by this student, the experience in Costa Rica promotes student development beyond a dualistic world view to a complex and informed world view. The experience also prepares and encourages them to be active participants in society as expressed by another student comment:

I think these trips are good. They show you the problems and at times touch you into wanting to do something. While reading about it makes you aware, it doesn't have the same impact. Just like seeing the green sea turtle, it makes you aware that other turtles are fighting for their existence - like the box turtle here in Pennsylvania. A book or a movie just doesn't have the same impact.

\section{Conclusions and Future Directions}

As evidenced by the findings, integrating curricular design and assessment provides an avenue to promote disciplinary learning gains in short-term study abroad courses. Incorporating inquiry-based and active learning in the design of such courses through pre-trip, field, and post-trip activities allows faculty to maximize the value of the field experience and document student learning gains.

The assessment findings suggested several improvements that might increase student learning in future classes. First, an introduction to writing field journals is needed as part of the pre-trip assignment. This introduction should be designed to provide students a set of guidelines to help focus them on connecting pre-trip reading materials and field lectures to describe specific environmental phenomena. Second, the course would benefit from reducing the number of regions studied to allow more time in specific regions so that the material can be covered in more depth. Finally, students would benefit from a requirement to summarize discussions that occurred after the field lectures.

Hard data tells us that time is running out for our "living" planet. In order to maintain its biodiversity (the variety of genes, species, and ecosystems that exist in our biosphere and allow us to keep evolving and enjoying "life" as we know it), it's never been a more important time for biological educators to 
commit themselves to fostering environmental advocacy among their students. Yet, biology teachers looking to build environmental ethics face a huge barrier: Most students are estranged from the natural world. They lead a "buffered" existence within human-built environments (Leopold, 2004) or techno-ecosystems (Naveh, 1982). Their exposure to living organisms takes place predominantly in zoos and aquariums, or, even more remotely, through gazing at color-coded diagrammatic pictures and figures in packaged textbooks.

In order to nurture our students' knowledge of and affection for the land, we need to do more than merely transmit stale biological principles. Furthermore, for students to understand the urgency of the challenges, they need a deep understanding of biological concepts to appreciate the severity of environmental risks. Short-term study abroad field experiences focusing in the biological sciences provide the opportunity for students to both see the world "unbuffered" and to contextualize that vision in a strong foundation of biological knowledge.

More university faculty are needed who see themselves teaching in 'classrooms without walls,' as leaders who can positively impact our young citizens beyond test scores, and as trained professionals who can organize and carry out short-term study abroad courses. It is recommended that the university, working more closely with International Programs, do more to allow and train its faculty to become 'visionary' teachers, not mere lecturers at a podium or laboratory supervisors. A university, in time, could build a list of faculty who teach 'short-term study abroad' courses whose connecting thread is interdependence. All students, in any discipline, could then take, at some juncture in their undergraduate career path, a course that will open their eyes to the interconnected world in which they live. Exposing our students to the realities of the 'real' world through study abroad promotes experiences in rich environmental contexts through experiential learning. It is a quintessential pedagogical approach that enhances the understanding of biological concepts and instills in students an environmental ethic. Our assessment of the Field Course Experiential Learning Model suggests that it promotes this type of understanding and ethic - and should be considered for application to other branches of study. 


\section{$R$ e f e r e n c e s}

Achard, F., H.J. Stibig, P. Mayaux, J. Gallego, T. Richards, and J.P. Malingreau. 2002. Determination of deforestation rates of the world's humid tropical forests. Science 297: 999-1002.

Anderson, L.W. and Krathwohl (Eds). 2001. A Taxonomy for Learning, Teaching, and Assessing: A Revision of Bloom's Taxonomy of Educational Objectives. New York: Addison Wesley Longman, Inc.

Bloom, B.S. (Ed.), Engelhart, M.D. Furst, E.J., Hill, W.H., \& Krathwohl, D.R. 1956. Taxonomy of Educational Objectives: Handbook 1: Cognitive Domain. New York: David McKay.

Brook, B. W., Sodhi, N. S. and Ng, P. K. L. 2003. Catastrophic extinctions follow deforestation in Singapore. Nature 424: 420-423.

Creswell, J.W. 1997. Qualitative inquiry and research design: choosing among five traditions. Thousand Oaks, Calif.: Sage Publications.

Johnson, D.K., Ratcliff, J.L. 2004. Creating coherence: the unfinished agenda. New Directions for Higher Education 125, 85-96.

McKee, J.K., P.W. Sciulli, C.D. Fooce, and T.A. Waite. 2004. Forecasting global biodiversity threats associated with human population growth. Biological Conservation 115: 161-164.

McLaughlin, J. S. (2005). Classrooms Without Walls: a banana plantation, a turtle nest, and the random fallen tree. International Educator, 14(1), 52-54.

Project Kaleidoscope, 1991. What Works: Building Natural Science Communities. Washington, DC: Statemants Communications.

Pimm, S. L. et al. 1995. The future of biodiversity. Science 269, 347-350.

Pounds, J.A., Puschendorf R. 2004. Ecology: Clouded futures. Nature 427, 107-109.

Rosser, A.M., Mainka, S. A. 2002. Overexploitation and species extinctions. Conservation Biology 16(3), 584-586.

Sala, O. E. et al. 2000. Global biodiversity scenarios for the year 2100. Science 287, 1770-1776.

Secretariat of the Convention on Biological Diversity (2006). Global Biodiversity Outlook 2. Montreal, 81 + vii pages.

The University Exchange. 2004. World Population Growth. Available online at www.edu.ue-foundation.org/worldpop.html.

Thomas, C.D., A. Cameron, R.E. Green, M. Bakkenes, L.J. Beaumont, Y.C. Collingham, B.F.N. Erasmus, M. Ferreria De Siquieira, A. Grainger, L. Hannah, L. Hughes, B. Huntley, A.S. Van Jaarsveld, G.F. Midgley, L. Miles, M.A. Ortega-Huerta, A.T. Peterson, O.L. Phillips, and 
S. E. Williams. 2004. Extinction risk from climate change. Nature 427, $145-148$.

Wilson, E. O. 2002. The future of life. New York, New York: Random House, Inc.

Wubbels, G.G., Girgus, J.S. 1997. The Natural Sciences and Mathematics. In Gaff, J.G., Ratcliff, J.L. 1997. Handbook of the Undergraduate Curriculum. San Francisco: Jossey-Bass.

Zervanos, S. M., McLaughlin, J. S. 2003. Teaching biodiversity and evolution through travel course experiences. The American Biology Teacher 65(9), 683-688.

\section{Suggested Additional Resources}

Acevedo, H., Bustamante, J., Paniagua, L., Chaves, R. 2003. Ecosistemas de la cuenca hidrográfica del río Savegre - Costa Rica. Santo Domingo de Heredia, Costa Rica: INBio.

Alfaro, E. 2003. Common plants of Chirripo national park. Heredia, Costa Rica: INBio.

Beletsky, L. 1998. The ecotravellers' wildlife guide to Costa Rica. San Diego: Academic Press.

Carrillo, E., Wong G., and Saenz, J. 2002. Costa Rica Mammals. 2nd edition. Santo Domingo de Heredia, Costa Rica: INBio.

Franke, J. 1999. A visitor's guide to Costa Rica's national parks and preserves. Seattle: The Mountaineers.

Frankie, G.W., Mata, A., Vinson, S.B. 2004. Biodiversity conservation in Costa Rica: Learning the lesson in a seasonal dry forest. Los Angeles: University of California Press.

Janzen, D.H. 1983. Costa Rican natural history. Chicago: University of Chicago Press.

Kappelle, M., Horn, S. P. 2005. Páramos de Costa Rica. Santo Domingo de Heredia, Costa Rica: INBio.

Leenders, T. 2001. A guide to amphibians and reptiles of Costa Rica. Miami: Zona Tropical.

Morales, F. 2000. Bromelias de Costa Rica / Costa Rica Bromeliads. INBio. Heredia, Costa Rica: INBio.

Sánchez, J. E. 2002. Aves del Parque Nacional Tapantí = Birds of Tapantí National Park. Santo Domingo de Heredia, Costa Rica: INBio.

Stiles, F.G., Skutch, A.F. 1989. A guide to the birds of Costa Rica. Ithaca, New York: Cornell University Press. 


\section{Appendix A \\ Pre-Trip Activities and Research}

Pre-trip Assignment \#1: Before you know it, we will be in Costa Rica experiencing firsthand what we have only been dreaming and/or reading about. The purpose of this assignment is to give you some general background knowledge about Costa Rica, so that your visit will be more meaningful and enlightening. On the web, go to the course site (www.lv.psu.edu/jxm57/explore/costarica/), and click on the "Outline" tab to find links to sites where you will be able to find the answers to the questions below.

You will have to read and sift through the information on these sites to find the answers. Search the web for other sites if necessary, and to further explore. You will quickly find that you can't learn enough about this fascinating country. I am looking forward to reading your thoughts and insights.

\section{Assignment \#1}

The following questions are based upon websites found in sections A. "Costa Rica - General Information" and B. "Costa Rican Culture."

1. Geography. How big is Costa Rica? How does its size compare to the United States? Is Costa Rica in a different time zone than Pennsylvania?

2. Weather. What weather should we expect when we arrive in late July? What will the temperature be? (Hint: search using the name of the city where our plane lands) We'll be in Costa Rica in the middle of the "wet" season. Does that mean it will rain every day? Do they refer to this time as "winter" or "summer," and why?

3. History. Who were the indigenous peoples who inhabited the area? Are any still living? Who were the first Europeans to explore the area, and where did they settle? How did Costa Rica get its name, and what does it mean?

4. Government. What is the capital of Costa Rica? What form of government do they use? When he entered office, President Abel Pacheco proposed to include environmental guarantees in the Costa Rican constitution. Follow the link below to summarize his initiatives.

http://forests.org/articles/reader.asp?linkid=16112 Search for articles with updated information. What has Pacheco accomplished so far? How have his proposals been viewed by the public? 


\section{Economy.}

A) Discuss the economy of Costa Rica. Are there any major exports? Imports? Are they experiencing economic growth

B) With regard to banana plantations, there are many problems in this industry related to the health of the workers and the environment. Summarize the following article that was published in the Costa Rican newspaper, The Tico Times, by a Nicaraguan correspondent, and then state your opinion. You may research this issue further in order to strengthen your opinion.

6. People. A) Costa Rica is unquestionably the most homogeneous of Central American nations in race as well as social class. Explain this statement by researching 'Costa Rican ethnicity.'

B) Every nationality has its own sense of identity. Costa Ricans have their own unique 'Tica' identify. Explain in full.

C) What language do most Costa Rican speak? What is their dominant religion?

7. Education. What percentage of the people of Costa Rica is literate? How many years of school do most children attend? What percentage of the national budget is spent on education? (Find out what percentages of our federal and state budgets are devoted to education.)

8. Trivia. Who, from Costa Rica, won a Nobel Peace Prize in 1987? For what accomplishment was he recognized? Also, name the astronaut from Costa Rica. What experiments did he conduct in space? What holiday will they celebrate in Costa Rica on August 2?

9. "You can count on a Tico's loyalty, but not on his punctuality." What in the world is a Tico? How did they get this name? What makes these people special?

¿Quien dice que no hay “Ticos” en Internet? Give a synopsis of some of the headlines in this week's The Tico Times. (www.ticotimes.net) Have fun here. Read! 


\section{Appendix B \\ Costa Rica Field Presentation}

Costa Rica Field Presentation: As a Penn State undergraduate student, a field presentation is a required assignment and, as you will come to see, is one part of my 'classroom without walls' module for experiential learning. So, let's get right to business so that you can shine in the Costa Rican rainforests!

Below is a list that showcases possible presentation topics. You may choose any of these or select a topic of your own. The key here is that you stay within the realms of environmental biology and conservation science.

- Contribution of Inbreeding to the Extinction Risk in Top Predators

-Over Harvesting: In Costa Rica and Our Own Backyard

- Biological Hotspots: In Costa Rica and Around the World

- The Story Behind the Banana

— Global Warming, HIPPO and Sustainability

— Sustainable Agriculture through Soil Conservation

- Global Amphibian Decline

- Integrated Pest Management

- Renewable and Non-Renewable Resources

- Will Hydrogen End Our Fossil Fuel Addiction

-Global Oil Production: What Happens When We Run Out?

— Global Fisheries and Costa Rica's Role

- The Costa Rican Shark Industry

- Tropical Rainforest Productivity and Deforestation

- Raptor Ecology and Migration

- Symbiotic Relationships

- Leatherback Turtle: Biology, Life Cycle, Threats, and Conservation Efforts

My job is to verify that each of you selects an appropriate topic and that your references and outline meet PSU 297 and 497 course approvals for content, depth, presentation, and research.

My job is to verify that each of you selects an appropriate topic and that your references and outline meet PSU 297 and 497 course approvals for content, depth, presentation, and research. 


\section{General Sources}

1. The Future of Life by Edward O. Wilson

2. Climate Change and Biodiversity by Thomas E. Lovejoy (which can be purchased from Amazon.com for \$35.00; ISBN \# 0-300-11980-1).

We will be using these books for discussion throughout our trip and relating their content to our Costa Rican experience.

\section{Guidelines}

1. Develop a 30-minute presentation pertaining to a topic relating to conservation biology in Costa Rica. At all times, concentrate on the environmental science and ecological concept(s) that are key to your topic and be sure to explain them. Whenever possible relate your topic to the actual Costa Rican habitats that we will explore and those of our own biome, the northeastern deciduous forest. For example I will use Ashley's presentation on "over-harvesting." Ashley first presented what is meant by "over harvesting" (what it is, how it relates to Hippo, etc.) itself. She then related this concept to the plight of Scarlet Macaw that inhabits the tropical lowland rainforest of Costa Rica, and then to the plight Pennsylvania Box Turtle.

2. Each presentation will be followed by a discussion period. It is suggested that you prepare a one page handout with discussion prompts, charts, graphs, figures, web sites, etc. These will be handed out the day before your presentation itself (30 copies). Please laminate your hand-out or cover it with a plastic coating.

3. There will be 22 presentations. My presentation, "The Realities of Water on a Global Scale," will occur first, so as to set the stage. On the last evening, there will also be a final session wherein I will lead a session called "Reflections on our Costa Rican Experiences."

4. When you choose a topic, please communicate via e-mail to me. Topic selection is due by May 10, 2005.

5. Once I approve your topic, please proceed to create a list of references for your outline. This is due by June 1, 2005. After this date, I will review your outline and make any necessary comments or suggestions.

6. A detailed outline of your presentation is due June 20, 2005. 


\section{Appendix C \\ Species Assignment}

Species Assignment: Students taking the Biology 297 credits are required to research one selected Costa Rican endemic plant or animal species. Students taking Biology 497 credits are required to research two-selected Costa Rican endemic plant or animal species

During your trip you should have researched as much as possible about your selected organism(s) by asking questions, using field guides, etc. Now that you are settled, you may wish to research your organism(s) in more depth. Please answer the following questions as thoroughly as possible using complete sentences:

1. What is the scientific name of the species? Common name?

2. Where was the organism spotted (if at all; if not spotted, where could we have seen it)?

3. What is the range and habitat of the species?

4. What is its evolutionary history? (origin, relatives etc.)

5. What role does it play in its environment (niche)? Is it a keystone species?

6. Any unique adaptations?

7. Any unique behavioral characteristics?

8. Any unique interspecific interactions like competition, predation, and commensalism?

9. Elaborate on the species food chain.

10. Is it an endemic species to Costa Rica? If not, where else is it found?

11. What are the threats to its survival?

12. What conservation efforts, if any, are presently being undertaken to protect this organism's survival? 


\section{Appendix D}

\section{Post-Trip Questions}

Post-trip Questions: Please answer the following questions. It was suggested that you kept them in mind and wrote some of your answers throughout your travels. It is imperative that you write clear and concisely, and keep Costa Rica's biomes and biodiversity alive in your writing. Complete sentences are mandatory.

a. In general, what impressed you the most about Costa Rica?

b. Overall, what were your best and worst experiences?

c. Any surprises or disappointments throughout the trip?

d. What did you learn about the biodiversity of the different types of Costa Rican rainforests? What was your favorite rainforest type visited and where was it? Why was it your favorite?

e. What did you learn about the biodiversity and ecology of paramo?

f. What problems, if any, concerning biodiversity did you uncover in Costa Rica? And are there solutions?

g. How have human activities impacted the natural habitats of Costa Rica?

h. What are your opinions on the future of Costa Rica's biodiversity?

i. From what you have experienced either directly or indirectly in the field, and through your extraneous use of textbooks and other resources to understand basic environmental science and ecology concepts, elaborate on three of the following items being as thorough as possible: (1) a example of a keystone specie(s) exerting strong controls on community structure in La Selva [you have to think about this one. I will be happy to verify your choice(s)]; (2) the affects of abiotic factors on Leatherback hatchling success in Gandoca (you may want to carry out the "Plight of the Leatherback" module for guidance here); (3) the affects of climate and local geography on the distribution of lowland tropical, pre-montane, cloud forest, and paramo (alpine forest) in Costa Rica; (4) what is meant by ecological succession seen in the primary rainforest of La Selva following a natural disturbance; (5) the dynamic 
biological processes affecting the population of Leaf-Cutter Ants in La Selva; and (6) the species diversity (species richness and relative abundance) of the lowland land tropical rainforest vs. the northeastern deciduous forest (re: E. O. Wilson's Latitude Density Model).

i. Give an example of three key concepts of biodiversity that you experienced firsthand in the field. Examples: keystone species exerting strong controls on community structure, affects of abiotic factors, affects of biogeographic factors, ecological succession, and disturbance and community structure. Elaborate on how these experiences impacted your learning.

j. Now that you are back in the United States, do you think differently about conserving natural habitat and biodiversity in Pennsylvania? Elaborate.

k. Now that you have experienced conservation biology research on an international and interdisciplinary level, do you feel you will return to Pennsylvania better able to educate your peers, family and friends on sustaining what's in their own backyard? Please elaborate. 